\title{
Upward lightning attachment analysis on wind turbines and correlated current parameters
}

\author{
Vogel, Stephan; Ishii, M. ; Saito, M. ; Natsuno, D.
}

Published in:

IEEE Transactions on Power Systems

Link to article, DOI:

10.1541/ieejpes.138.327

Publication date:

2018

Document Version

Peer reviewed version

Link back to DTU Orbit

Citation (APA):

Vogel, S., Ishii, M., Saito, M., \& Natsuno, D. (2018). Upward lightning attachment analysis on wind turbines and correlated current parameters. IEEE Transactions on Power Systems, 138(5), 327-332.

https://doi.org/10.1541/ieejpes.138.327

\section{General rights}

Copyright and moral rights for the publications made accessible in the public portal are retained by the authors and/or other copyright owners and it is a condition of accessing publications that users recognise and abide by the legal requirements associated with these rights.

- Users may download and print one copy of any publication from the public portal for the purpose of private study or research.

- You may not further distribute the material or use it for any profit-making activity or commercial gain

- You may freely distribute the URL identifying the publication in the public portal

If you believe that this document breaches copyright please contact us providing details, and we will remove access to the work immediately and investigate your claim. 


\section{Upward lightning attachment analysis on wind turbines and correlated current parameters}

Vogel, Stephan; Ishii, M. ; Saito, M. ; Natsuno, D.

Published in:

Proceedings of 4th International Symposium on Winter Lightning

Publication date:

2017

Document Version

Publisher's PDF, also known as Version of record

Link back to DTU Orbit

Citation (APA):

Vogel, S., Ishii, M., Saito, M., \& Natsuno, D. (2017). Upward lightning attachment analysis on wind turbines and correlated current parameters. In Proceedings of 4th International Symposium on Winter Lightning

\section{General rights}

Copyright and moral rights for the publications made accessible in the public portal are retained by the authors and/or other copyright owners and it is a condition of accessing publications that users recognise and abide by the legal requirements associated with these rights.

- Users may download and print one copy of any publication from the public portal for the purpose of private study or research.

- You may not further distribute the material or use it for any profit-making activity or commercial gain

- You may freely distribute the URL identifying the publication in the public portal 


\title{
Upward lightning attachment analysis on wind turbines and correlated
}

\author{
current parameters \\ S. Vogel, Technical University of Denmark, M. Ishii, University of Tokyo \\ M. Saito, Central Research Institute of Electric Power Industry, D. Natsuno, Toyo sekkei Co.
}

\begin{abstract}
This work provides insight in the attachment characteristics of upward initiated lightning discharges to wind turbines and their possible consequences for the lightning protection of wind turbine blades. All discharges were recorded at the Japanese coast of the Sea of Japan which is known for intense upward lightning activity. 172 video recordings of lightning discharges on rotating wind turbines are analysed and attachment angle, detachment angle, and the resulting angular displacement were determined. A classification between self-initiated and other-triggered upward lightning events is performed by means of video analysis. The results reveal that the majority of discharges are initiated on vertical blades; however, also attachments to horizontal blades are reported. Horizontal attachment (or a slightly inclined blade state) is often related with a triggered lightning event prior to the discharge. There are about twice as many lightning attachments during the ascending blade movement compared to the descending blade movement. Furthermore, a comparison between current parameters from stationary and rotating wind turbines reveal no substantial difference between the two operational modes. The dataset of video recordings and current measurements originates from the Japanese New Energy and Industrial Technology Development Organization Furthermore (NEDO) measurement campaign $(2008$ - 2013) which documented lightning incidences on wind turbines mainly during the winter season at the Sea of Japan.
\end{abstract}

Keywords : Wind Turbine, Upward Lightning, Attachment, Self-initiated, Other-triggered, Winter Lightning

\section{INTRODUCTION}

Upward initiated lightning incidences pose a severe threat to the integrity of wind turbines. Unlike downward lightning leaders, which are initiated in the cloud and approach the ground following a random like path, upward lightning leaders start from the extremities of tall objects. The point of leader initiation is determined by the point of maximum electric field enhancement, which in turn promotes the attachment of multiple consecutive lightning discharges to the same location. This may also be a reason for the increased amount of reported damages in the so called "Winter Lightning Areas" where repetitive upward lightning attachments are reported on elevated structures such as towers and wind turbines.

In the literature, four different aspects are described to have an impact on the amount of upward lightning incidences on an arbitrary chosen location. First, the height of a structure increases the amount of receiving upward lightning incidences, where buildings exceeding 100 meters start to show upward lightning activity[1]. Second, the topography of the site, where elevated terrain such as mountain ridges promote the appearance of upward lightning [2][3]. Third, the meteorological conditions and local temporal weather characteristics, as seen at the Sea of Japan $[4][5][6]$. These three factors refer all to an increase of electric field at ground level due to either elevated objects on ground or a reduced distance between cloud base height and the ground. The fourth factor relates to the local flash density which may, together with the characteristics of the structure, be responsible for upward

\section{Contact Address:}

Stephan Vogel

$\mathrm{Ph} . \mathrm{D}$. Student

Elektrovej, Building 325, Room 155, 2800 Kgs. Lyngby, Denmark

E-mail: stevog@elektro.dtu.dk lightning triggered by nearby cloud-to-ground (CG) and intra-cloud (IC) activity [7].

Several authors have published work regarding the lightning interaction with rotating wind turbine blades. Recently, it had been suggested that the rotation of a wind turbine blades can promote the initialisation of upward lightning discharges due to absence of accumulated space charge around the tip region which increases the local electric field, leading to a higher probability of lightning leader formation [8]. The interaction between the rotation of wind turbine blades and dart leader return strokes from upward lightning flashes was numerically analysed in [9]. It is found the tip region of a wind turbine blade is the expected starting point for upward lightning leaders, however; dart leader return strokes may attach to the nacelle or close to the root of the blade but are not able to explain observed damages in the near vicinity of the tip section (1-6 meter from the tip of the blade). Enhancement of attachment to the tip region of the wind turbine blades is further acknowledge by the work in [10].

In this work, video recordings of lightning attachments to rotating wind turbines are used to characterise the attachment, detachment and angular displacement of the lightning channel. Furthermore, a classification between self-initiated and other-trigger lightning incidences is performed. Current waveform recordings from 115 out of 172 events classify evidently the lightning as upward directed. From the remaining 57 lightning events no evident propagation direction can be derived due to the lack of a current measurement; however, studies regarding the lightning exposure of wind turbines along the Japanese coast of the Sea of Japan indicate that $98.5 \%$ of all lightning activity in winter is classified as upward lightning [11]. Therefore, this work represents the investigation of upward lightning incidences from wind turbines and may not relate to the attachment process of natural downward lightning. 


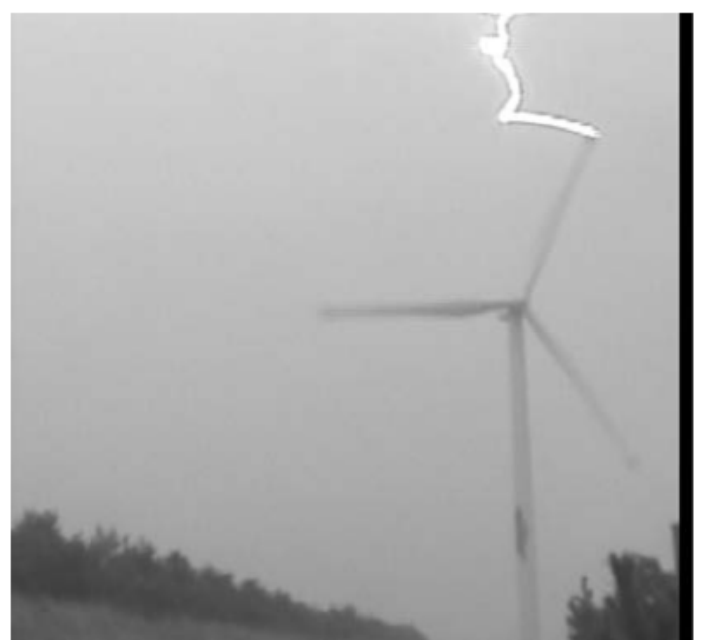

Figure 1. Typical upward lightning on WT. The plasma channel is swept due to the angular velocity of the tip receptor.

The data originates from a Japanese $R \& D$ research project funded by the New Energy and Industrial Technology Development Organization Furthermore (NEDO) [12]. From 2008 - 2013, lightning current measurements, lightning video observations, and damage reports were collected which provided substantial knowledge of upward lightning discharges to the scientific and industrial community. Various international publications were created as a matter of this project[11][13] [14].

\section{ATTACHMENT ANALYSIS OF ROTATING WIND TURBINE BLADES}

As the first part of this work, 172 video recordings from lightning attachments on rotating wind turbines are analysed in order to document lightning discharge behaviour which can be used to validate or reject numerical models. All discharges were recorded in the non-convective months from November - April. Characteristic for the interaction of long duration lightning flashes with rotating wind turbines are the swept lightning channels which form after the upward lightning leader attached to a charge pocket in the cloud (Figure 1). The plasma channel, which is attached to the metallic tip receptor, is dragged along the circumference of the rotor and exposing the trailing edge of the blade to a high energetic arc.

This work investigates 12 wind turbines which are located along the Sea of Japan as indicated in Figure 2. The video recording system captured images with $30 \mathrm{fps}$ which provides one picture every 0.033 seconds. Even though the frame rate is low, due to the characteristic long duration discharges from the winter discharges in Japan, the recordings provide sufficient quality.

Figure 3 illustrates the angular reference frame which is used in this work. $180^{\circ}$ represents a vertical blade facing upwards, whereas $90^{\circ}$ and $270^{\circ}$ represent horizontal blade alignment with ascending and descending blade movement, respectively. All angle estimations are derived by visual inspection of video data and may be biased by subjective error. An accuracy tolerance of $\pm 10^{\circ}$ may be assumed. The blue area indicates the angle where a lightning stroke was attached to the blade and swept along the trailing edge of the receptor. In Figure 4 each individual lightning incidence is represented by a bar which provides information about the attachment angle, the detachment angle and the resulting displacement angle. Several observations can be drawn from this figure. Attachment of lightning strokes was recorded from $90^{\circ}$ to $270^{\circ}$. The longest observed discharge was characterised by a timespan of 0.63 seconds, attached to the blade around $200^{\circ}$, and detached at an angle of $340^{\circ}$, where the blade was nearly facing vertically towards the ground. The average visible timespan for a discharge was 0.22 seconds. 80 out of $172(46 \%)$ of all incidences appear between an angle of $170^{\circ}$ to $190^{\circ}$ which represents a vertical blade facing up. In 60 out of $172(35 \%)$ of the cases the attachment happened during the ascending movement $\left(<170^{\circ}\right)$ of the blade whereas in 32 out of $172(19 \%)$ of the cases, the blade was in descending movement $\left(>190^{\circ}\right)$. Therefore, upward lightning initiation is most frequently observed when the blade is vertical, which represents also the condition where the electric field is the highest. The ascending phase of rotation has about double the amount of discharges compared to the descending phase. One explanation for this observation could be that the electric field in the descending phase of the rotation is reduced by lagged space charges which built-up on the trailing edge of the blade. During the ascending phase; however, the electric field around the leading edge of the blade is not biased by space charges since the impact of the rotation sweeps them towards the trailing edge[8].

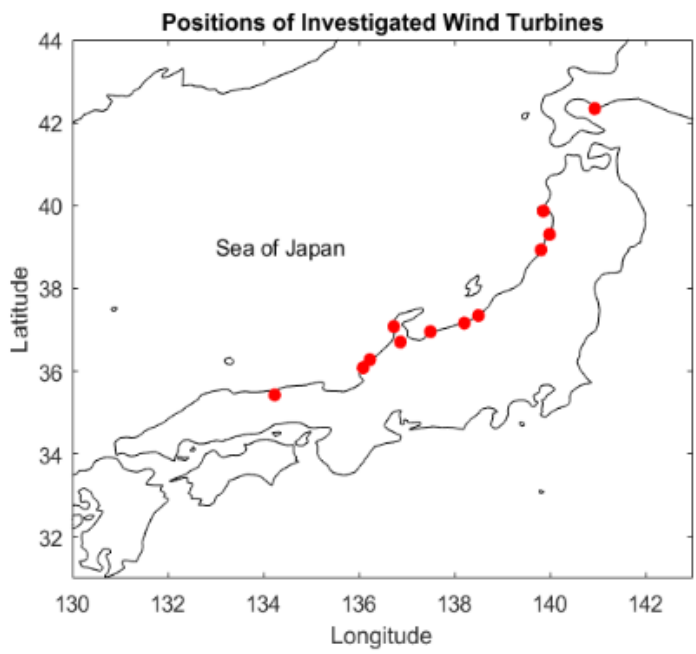

Figure 2. Investigated wind turbine locations in Japan

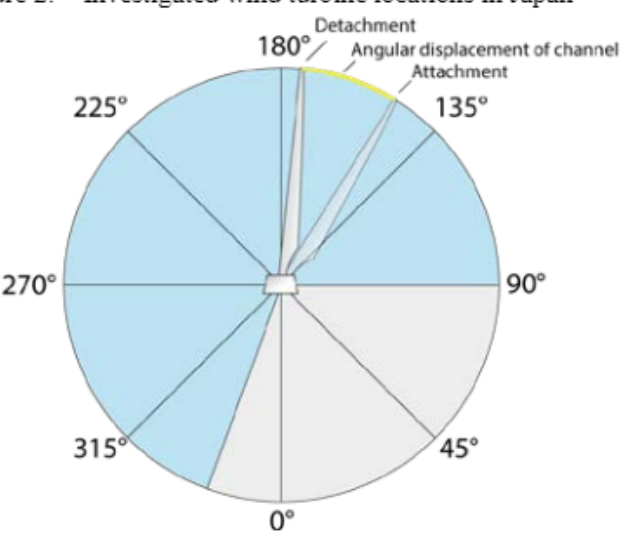

Figure 3. Angular reference frame. The blue area indicates the angle where the plasma channel was attached to the blade. 


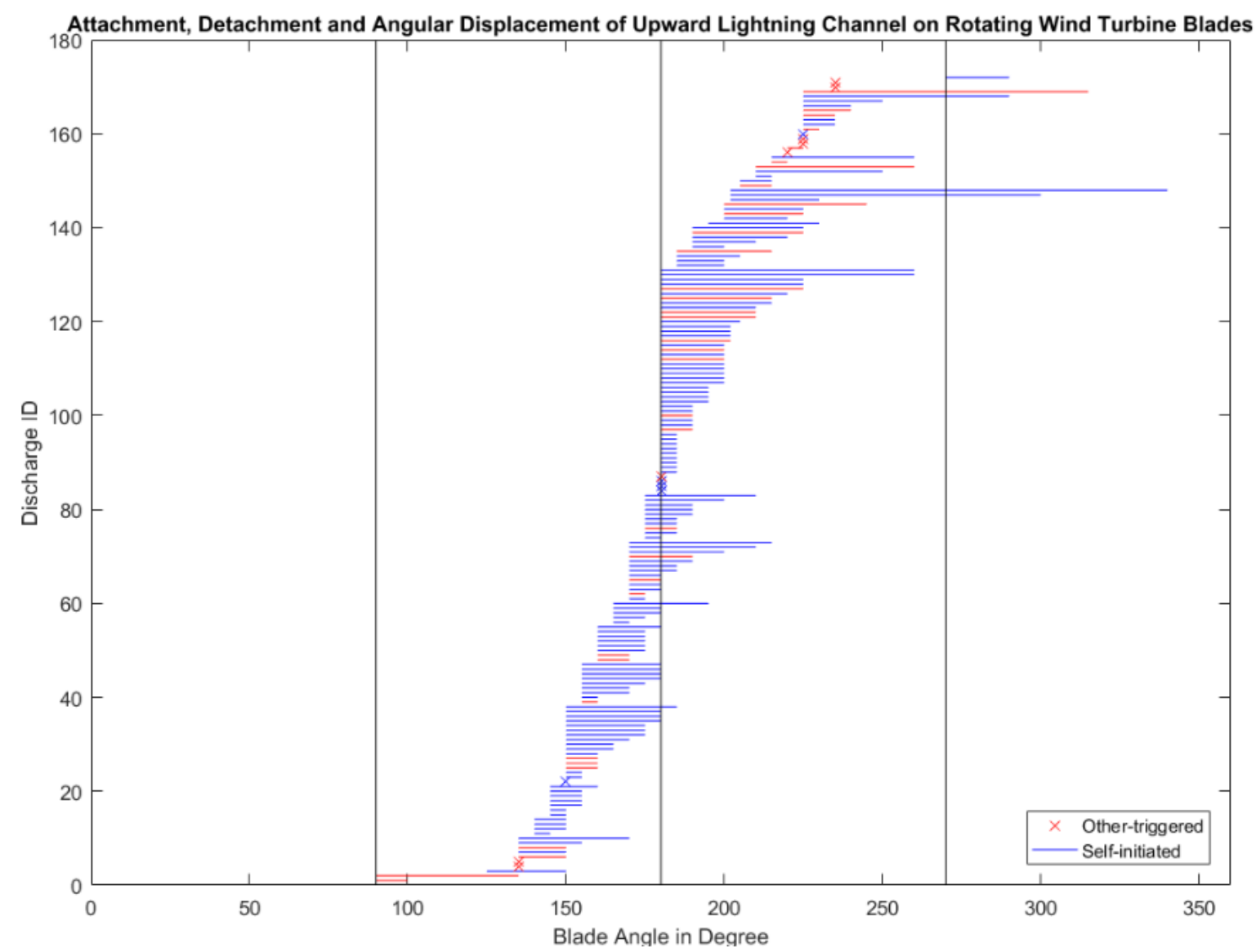

Figure 4. Attachment characteristics of 172 upward lightning discharges on wind turbine blades. Each bar represents an individual lightning discharge to a wind turbine. The start and the end postions indicates the attachment and detachment position of the blade, respectively. A cross indicates a short duration ( 1 frame) lightning event.

A short duration attachment, which was visible only for one frame, is indicated with a cross. 159 out of 172 video recordings were longer than two frames whereas the remaining 13 events showed lightning events for only one frame which may be classified as attempted leaders or very short duration incidences.

There was no observation of a simultaneous discharge from two blades or a lightning discharge which terminated in a new attachment point during the dart leader period (for instance nacelle or inboard). One out of 172 cases evidently developed an upward lightning leader from the nacelle. In this case, the rotor was in a Y position (blades at $135^{\circ}$ and $225^{\circ}$ ). Furthermore, a classification between self-initiated and other triggered lightning discharges is performed.

Each video recording was evaluated weather a visible lightning event was observed prior to the lightning attachment (indication: illuminated one - four frames before the attachment). Limitations apply with this classification since the video observations may not be able to show the preceding flash. Therefore, there is a possibility that a fraction of declared self-triggered lightning discharges may actually be other-triggered.

Nevertheless, Figure 4 shows that a high fraction of lightning discharges are self-initiated when the blade is vertical; however, discharges initiated from a horizontal blade experience a higher fraction of other-triggered sources. The angular dependencies between other-triggered and self-initiated upward lightning discharges are also illustrated in Figure 5. 43 out of 172 (25\%) upward lightning flashes are marked as other-triggered lightning events. Considering the tendency that a higher fraction of upward lightning flashes connect to a horizontal blade when triggered by another flash, the position and the vector of the triggering lightning discharge together with the resulting electric field change of the stroke may impact the starting point (even though the blade may not be vertical) of the upward leader.

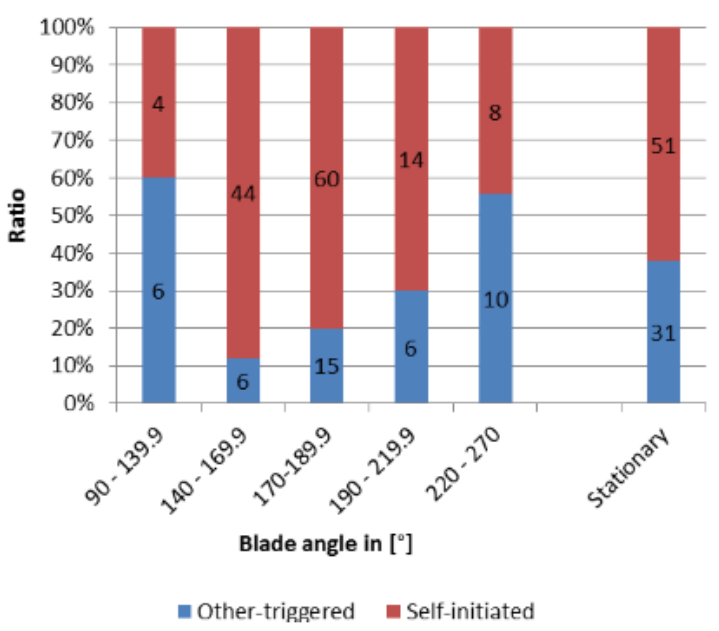

Figure 5. Separation of self-initiated and other-triggered lightning discharges according to the attachment blade angle. Amount of events in each category are indicated inside the bar plot. Last bar illustrates the ratio for the stationary case for comparison. 
The charge and specific energy as a function of flash duration is illustrated in Figure 6 and Figure 7, respectively. From the graphs it can be seen that a long flash duration is not automatically correlated to a high value of charge or energy. Initial continuous currents of a few hundred amperes can establish such relatively weak and long duration flashes. Charge values above $300 \mathrm{C}$ were recorded in a with a time period of 0.2 -0.47 seconds.

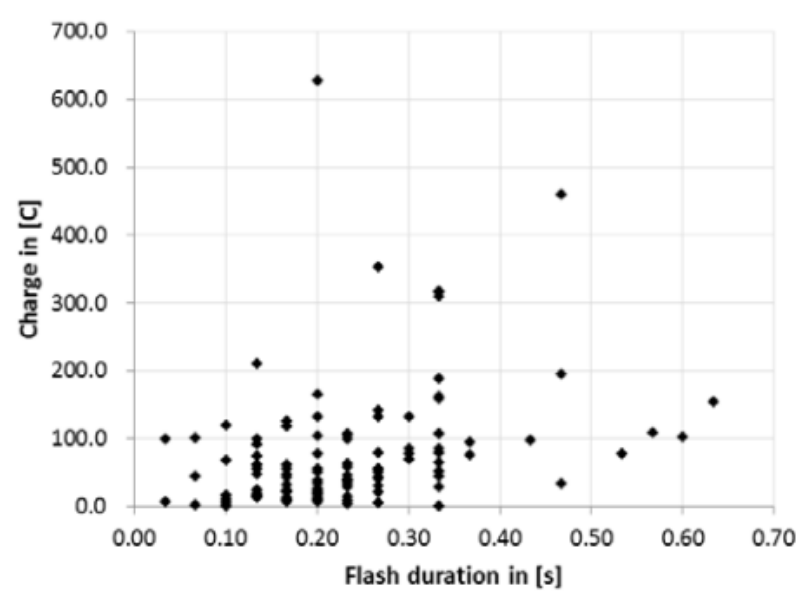

Figure 6. Charge amount of upward lightning flashes as a function of flash duration

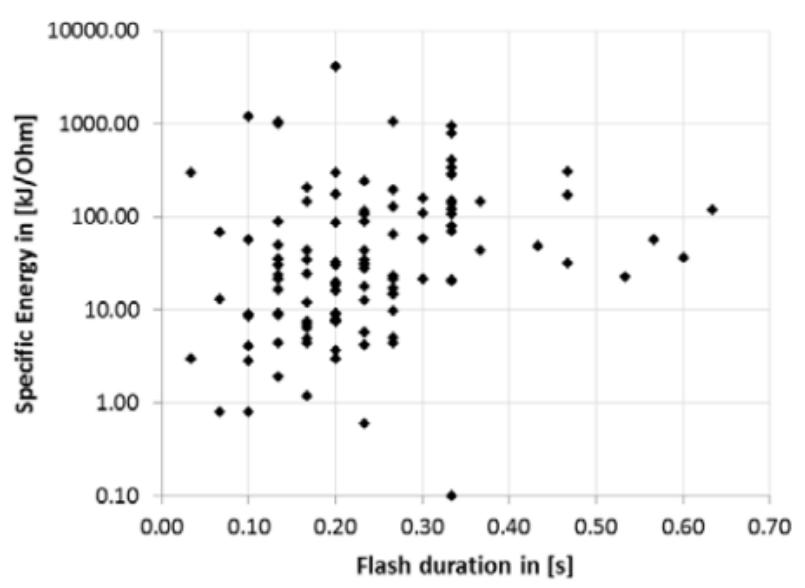

Figure 7. Specific energy of upward flashes on rotating wind turbines as a function of flash duration

\section{CURRENT RELATED DERIVATIVES FROM STATIONARY AND ROTATING BLADES}

In this section, some derivatives from current parameters of rotating and stationary wind turbines are briefly compared to investigate if there are distinct differences between the two scenarios. Simultaneous current measurements and video recordings were available from 43 flashes on stationary wind turbines and 115 flashes on rotating wind turbines. The data was measured by utilization of Rogowski Coils. Further information about implementation, acquisition and data post processing of the system can be found in [11].

Figure 8 and Figure 9 illustrate the probability distribution of charge and specific energy, respectively. Seven out of a total of 158 flashes exhibited larger charge amounts than $300 \mathrm{C}$, which is the maximum charge value for a flash for Lightning Protection
Level (LPL) 1 for wind turbines according to [15]. On the other hand, none of the flashes exceed the specific energy testing requirement of $10 \mathrm{MJ} / \mathrm{Ohm}$. As can be seen, only slight differences between the rotating and stationary discharges can be found. The charge does not show particular differences apart that the two highest values are related to the rotating state. The specific energy of stationary wind turbines is slightly reduced between the $50 \%$ to the $90 \%$ area; however, above $300 \mathrm{~kJ} / \mathrm{Ohm}$ the differences are minimal. Interestingly, all measured upward lightning discharges on stationary wind turbines which exhibited higher charge values $(>100 \mathrm{C}$ and $1 \mathrm{MJ} / \mathrm{Ohm})$ were situations when the wind turbine was manually shut-off due to thundercloud warning systems (several wind power plants in Japan need to be turned-off during thunderstorm activity as a safety policy) and not due to of a lack of wind. This statistics shows that disabling wind turbines during stormy conditions does not provide protection from flashes with high charge and specific energy content. Furthermore, flashes which are intercepted on stationary wind turbines due to weak ambient wind speeds are likely to have limited charge and specific energy content. The reason for the occurrence may be a limited charge separation process as a result of the low resulting vertical updraft velocity.

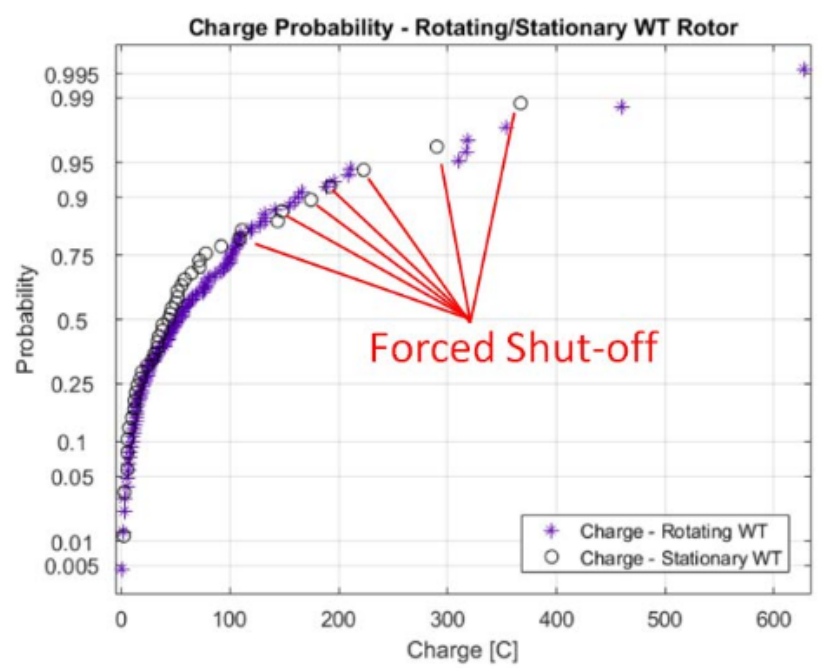

Figure 8. Charge distribution of rotating/stationary wind turbines. On stationary wind turbines, charge values above $100 \mathrm{C}$ were measured when turbine was stopped manually.

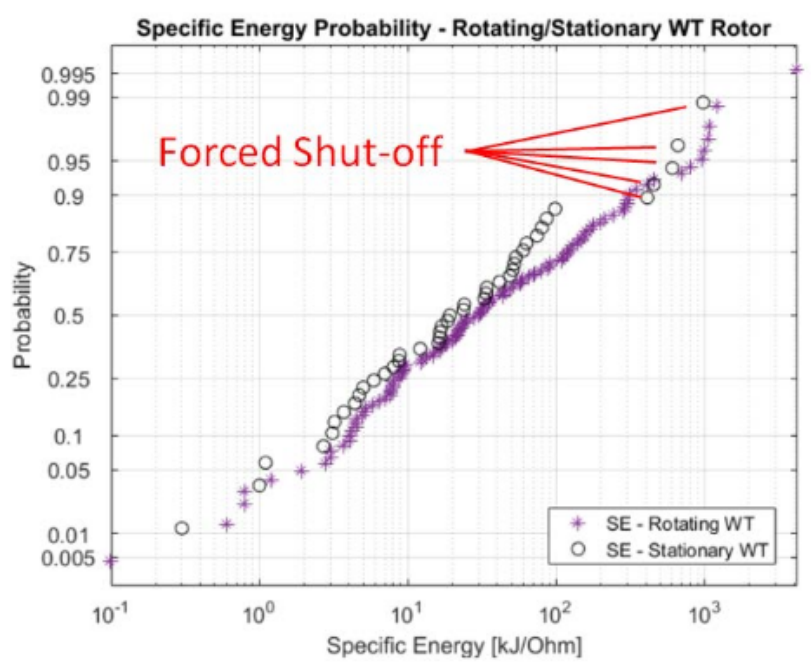

Figure 9 . Specific energy of rotating/stationary wind turbines. On stationary wind turbines, specific energy values above $1 \mathrm{MJ} / \mathrm{Ohm}$ were measured when turbine was stopped manually 
Also the current peak parameters show only minor differences, with a tendency that stationary wind turbines experience slightly lower mean peak current values. Peak current values of upward lightning are reported to be well below $50 \mathrm{kA}$ with only a few exceptions. Concluding from this statistic, there is no evidence that the exposure intensity (current parameters) vary depending on the rotating and stationary state. From this point of view, the decision to turn-off wind turbines during or before thunderstorm activity as a protection measure might not be justified; however, disabling wind turbines may help to prevent an extension of damages after lightning impact.

\section{CONCLUSION}

This work presents the results of an extensive video analysis of upward lightning discharges to wind turbines, which were recorded in the winter months from 2008 - 2013. The attachment point, detachment point and the duration of 172 upward lightning discharges to rotating wind turbines are investigated. Characteristic for upward lightning are the long duration discharges which can transfer high amount of charge to the ground. Shortly after the leader connected to a charge pocket in the cloud, the plasma channel is pushed towards the trailing edge due to the resulting velocity of the blade tip. Therefore, the majority of the energy of the flash will enter the wind turbine from the trailing edge of the tip receptor. Furthermore, the arc may cause pollution of the non-conducting glass-fibre material around the receptor due to vaporized metal, which, in turn, can influence the susceptibility to blade puncture. Wind turbines manufacturers operating in severe upward lightning areas should address these observations in their receptor design.

Flashes were characterized into self-initiated and other-triggered events by means of video analysis. Even though a fraction of flashes may have been misclassified, the tendency that horizontal blade alignments are triggered by other flashes was established. Furthermore, the attachment angle of other-triggered lightning events are scattered throughout the circumference from $90^{\circ}$ till $270^{\circ}$. Self-initiated discharges are most frequently observed at vertical blade alignment. A comparison of current parameters from stationary and rotating rotors reveal no substantial differences between the two operational modes.

\section{ACKNOWLEGDEMENTS}

The author is grateful to NEDO project for data access and agreeing to present the content of this paper.

The research has been partly funded by the Danish Energy Agency through the Energy Technology Development and Demonstration Program (EUDP), as part of the ELITE [16] project.

\section{References}

[1] A. J. Eriksson, "The incidence of lightning strikes to power lines," IEEE Trans. Power Deliv, vol. PWRD-2, no. 3, pp. 859-870, 1987.

[2] F. a M. Rizk, "Modeling of lightning incidence to tall structures Part I: Theory," IEEE Trans. Power Deliv., vol. 9, no. 1, pp. 172-193, 1994.

[3] A. C. Garolera, S. Vogel, J. López, S. F. Madsen, and K.
Bertelsen, "EFFECT OF LOCAL TOPOGRAPHY ON LIGHTNING EXPOSURE OF WIND TURBINES," in ICOLSE - International Conference on Lightning and Static Electricity, 2015, pp. 1-7.

[4] N. Kitagawa and K. Michimoto, "Meteorological and electrical aspects of winter thunderclouds," J. Geophys. Res. ..., vol. 99, no. D5, pp. 10713-10721, 1994.

[5] F. Fujii, M. Ishii, M. Saito, M. Matsui, and D. Natsuno, "Characteristics of winter lightning threatening wind turbines in coastal area of the sea of Japan," Electr. Eng. Japan (English Transl. Denki Gakkai Ronbunshi), vol. 184, no. 2, pp. 44-50, 2013.

[6] H. Zhou, G. Diendorfer, R. Thottappillil, H. Pichler, and M. Mair, "The Influence of Meteorological Conditions on Upward Lightning Initiation at the Gaisberg Tower," in International Conference on Lightning Protection (ICLP), 2014, pp. 923-926.

[7] T. A. Warner, K. L. Cummins, and R. E. Orville, "Upward lightning observations from towers in Rapid City, South Dakota and comparison with National Lightning Detection Network data , 2004 - 2010," J. Geophys. Res., vol. 117, no. D19109, pp. 2004-2010, 2012.

[8] J. Montonaya, O. van der Velde, and E. Williams, "Lightning discharges produced by wind turbines," $J$. Geophys. Res., vol. 119, pp. 1455-1462, 2014.

[9] M. Long, "On The Attachment of Lightning Flashes to Grounded Structures, Doctoral Thesis, KTH Royal Institute of Technology," 2016.

[10] S. F. Madsen, "Proposal of New Zoning Concept Considering Lightning Protection of Wind Turbine Blades," J. Light. Res., vol. 4, no. 1, pp. 108-117, 2012.

[11] M. Ishii, "NEDO R \& D Project for Measures of Lightning Protection of Wind Turbines in Japan," in International Symposium on Lightning Protection (SIPDA), 2015.

[12] "NEDO report 20150000000080, 'Research and Development of Next- Generation Wind Power Generation Technology for Technology Corresponding to Natural Environment etc. for Measures of Lightning Protection (FY2008-FY2012),' Annual Report of NEDO, Japan," 2015.

[13] M. Ishii, M. Saito, D. Natsuno, and A. Sugita, "Lightning Current Observed at Wind Turbines in Winter in Japan," in International Conference on Lightning and Static Electricity (ICOLSE), 2013, pp. 1-7.

[14] M. Ishii, M. Saito, Daisuke Natsuno, and A. Sugita, "Lightning Incidence on Wind Turbines in Winter," in International Conference on Lightning Protection (ICLP), 2014.

[15] IEC 61400-24, "IEC 61400-24 - Wind turbines - Part 24: Lightning Protection ed1.0," 2010.

[16] S. F. Madsen, S. Vogel, J. Lopez, A. C. Garolera, and K. Bertelsen, "ELITE - ENHANCED LIGHTNING EFFECTS TESTING CAPABILITIES," in International Conference on Lightning and Static Electricity (ICOLSE), 2015, pp. 1-8. 